\title{
TELAAH METAFISIK UPACARA KASADA, MITOS DAN KEARIFAN HIDUP DALAM MASYARAKAT TENGGER
}

\author{
Mohamad Anas \\ Mohanas@gmail.com \\ STAI Mațali'al-Falah Pati
}

\begin{abstract}
Abstrak
Dalam upaya mencari dimensi yang paling hakiki, manusia tidak boleh hanya berkutat pada level empiris dan apriori semata. Manusia harus melakukan perenungan dengan melepaskan diri dari segala sesuatu yang bersifat empiris dan apriori untuk menemukan prinsip utama. Tulisan ini menganalisis dimensi metafisik upacara kasada. Hasil kajian menunjukkan bahwa refleksi metafisik mampu 'mengatasi' realitas yang nampak, yang seakan-akan "sesungguhnya" namun pada kenyataanya 'menipu'. Kepalsuan ini tanpa disadari masuk ke dalam ranah ideologis dan membuat manusia tak mampu keluar dari sakralisasi ruang, waktu dan tempat yang mewarnai ritual upacara Kasada. Bertitik tolak dari penemuan ini, pelacakan dimensi metafisik dilanjutkan untuk menemukan eksistensi dan makna dari sebuah simbol-simbol dan mitos. Pelacakan ini pada akhirnya memberi kesimpulan bahwa dimensi metafisik dalam upacara Kasada masyarakat Tengger pada hakekatnya adalah miniatur dari kehidupan semua.
\end{abstract}

Abstract

A METAPHYSICAL STUDY ABOUT THE KASADA CEREMONY, THE MYTHS AND WISDOM OF LIFE IN THE TENGGER SOCIETY: In effortS to find the most essential dimension, people should not dwell on the level of empirical and a priori only. On the contrary, they have to do reflection and escape from everything empirical and a priori to find the main principles. This paper analyzes the metaphysical dimension of Kasada ceremony. The results showed that the metaphysical reflection is able to 'cope' with apparent reality, that is like a "real" but it is "false". This falsehood unwittingly enter into the realm of ideological and make 
people unable to get out of the sacralization of space, time and place that colored the ritual ceremony of Kasada. Following this discovery, the tracking metaphysical dimensions continue to discover the existence and the meaning of symbols and myths. This tracking ultimately concludes that the metaphysical dimension in Tengger Kasada ceremony is essentially a miniature of life of all.

Kata Kunci: Metafisik, Kasada, Mitos, Tengger

\section{A. Pendahuluan}

Dalam perspektif sejarah, dahulu masyarakat suku Tengger hanya mempunyai kepercayaan dinamisme dan animisme ${ }^{1}$ Seperti yang juga ditegaskan oleh Supriyono bahwa agama pertama dianut adalah kepercayaan terhadap ruh halus (animisme) dan kepercayaan terhadap benda-benda yang dianggap mempunyai kekuatan gaib (dinamisme). Tempat-tempat yang mempunyai nilai religi bagi masyarakat itu sampai sekarang masih tetap dilestarikan².

Sejak awal kerajaan Hindu di Indonesia, nama Tengger sudah dikenal dan diakui sebagai tanah hila-hila (Tanah Suci). Para penghuni daerah Tengger ini dianggap sebagai Hulun Spiritual Sang Hyang Widhi Wasa (Abdi Spiritual yang Patuh terhadap Tuhan Yang Maha Esa). Hal ini dapat dilihat dari prasasti-prasasti Tengger. Salah satu Prasasti Tengger yang terbuat dari batu menunjukkan angka tahun 851 Saka atau bertepatan dengan tahun 929 M. disebutkan bahwa sebuah desa yang bernama Desa Walandit yang terletak di pegunungan Tengger, adalah suatu tempat suci. Sebab, desa ini dihuni oleh para hulun Dewa-Dewi agama Hindu. ${ }^{3}$

Dalam sebuah naskah yang berasal dari Kraton Yogyakarta yang berangka tahun $1814 \mathrm{M}$, dituturkan bahwa daerah Tengger termasuk wilayah yang diberikan kepada Panglima Besar Patih Gadjah Mada oleh Kraton Majapahit karena prestasi kerjanya.

${ }^{1}$ Simanhadi Widyaprakoso, Masyarakat Tengger: Latar Belakang Daeah Taman Nasional Bromo, (Yogyakarta: Kanisius. 1994), h. 4

${ }^{2}$ Supriyano dan Misjana Wirtayuhangga. Di balik Keindahan Gunung Bromo. (Probolinggo: Tanpa Penerbit. 1991), h. 4

${ }^{3}$ Muslimin, "Pengaruh Kepemimpinan Uwā terhadap Motivasi dan Disiplin Kerja Masyarakat Tolotang di Kabupaten Sidrap”, Tesis, Universitas Hasanuddin Ujung Pandang, 1996, h. 25. 
Sehingga sampai abad ke-18 oleh Kraton Yogyakarta, para penghuni Tengger dinamakan sebagai tiang Gadjah Mada. Sekitar abad ke-15 Kraton Majapahit runtuh, semua tradisi yang pernah jaya hilang, kecuali masyarakat Hindu yang masih tetap bertahan di daerah pegunungan Tengger, mereka tetap setia mempertahankan tradisi, budaya dan spiritual mereka. ${ }^{4}$

Di abad ke-16 dan ke-17, Jawa bagian Timur mengalami kekacauan politik yang sangat serius, seperti perang saudara, penggarongan, dan musim paceklik. Pada awal abad ke-17, situasi politik di Jawa mulai terjadi adanya perubahan. Pusat pemerintahan bergeser dan mulai dikendalikan oleh Sultan Agung yang beragama Islam, sebagai Raja Mataram (1613 -1646 M.). Semua daerah di Jawa Timur dapat ditaklukkan dan dikuasai, kecuali daerah pegunungan Tengger yang tetap bersikukuh melawan kekuasaan Sultan Agung dan mereka tetap mempertahankan ajaran agama Hindu yang mereka anut. Walaupun pengganti Sultan Agung mencoba ingin menguasai daerah Tengger (pada tahun 1647 M.), namun usaha tersebut tetap sia-sia saja. Oleh sebab itu, daerah Tengger mempunyai kekhasan tersendiri terutama jika dibandingkan dengan tradisi kerajaan Mataram, khususnya wilayah Jawa tengah ${ }^{5}$.

Konteks sosio-politik di Jawa Timur pada zaman itu masih belum bebas dari perang dan kekacauan huru-hara politik. Pada tahun 1680 M pasukan Trunojoyo yang melawan Kraton Mataram dan Belanda, melarikan diri ke daerah Tengger. Demikian pula pasukan Untung Suropati, juga terdesak ke daerah Tengger ketika melawan tentara Mataram dan Belanda. Dalam perlawanan tersebut, baik Trunojovo maupun Untung Suropati banyak dibantu oleh orangorang Tengger. Baru pada tahun 1764 M., daerah Tengger dapat dikuasai oleh pasukan Belanda. Kraton Hindu di Blambangan juga dapat ditaklukkan pada tahun $1771 \mathrm{M}$. Dengan demikian, seluruh daerah Jawa Timur dapat dikuasai oleh Belanda. Dan pada saat itu maka semua tradisi Hindu hilang kecuali para penghuni Tengger yang dapat mempertahankan keberadaan tradisi Hindu yang merupakan warisan zaman Kerajaan Majapahit.

${ }^{4}$ Ibid.

${ }^{5}$ Ibid. 
Pada abad ke-19, terjadi perubahan situasi politik terutama di daerah-daerah lain yang termasuk padat penduduk, sehingga banyak orang luar daerah Tengger yang berdatangan ke Tengger. Hal ini mengakibatkan jumlah penduduk di sekitar daerah Tengger menjadi lebih besar. Daerah-daerah tersebut di antaranya adalah Poncokosumo, Gubuk kelakah, Nongkojajar, Sukapura, dan daerah Sumber. Namun tradisi adat masyarakat ini terpisah dengan tradisi adat masyarakat suku Tengger. Pada abad ini pula, pemakaian istilah Budha di Tengger digunakan untuk membedakan dan menegaskan bahwa orang Tengger tidak memeluk agama Islam. Hal ini dapat dipahami karena pada zaman kerajaan Majapahit, agama yang berkembang besar dan pesat adalah agama Budha dan Hindu. Jika orang Tengger menyatakan dirinya beragama Budha, bukan berarti mereka mengakui Sidharta Gautama. Namun mereka sangat yakin bahwa agama yang dianutnya adalah keturunan agama Hindu yang murni. Bahkan hanya daerah Tengger yang menurunkan tradisi spritual yang beradasarkan prinsip-prinsip agama Hindu yang berlaku sejak Zaman Majapahit. ${ }^{6}$

Setelah Indonesia merdeka, pemerintah melakukan pembinaan terhadap keberadaan agama dan kepercayaan yang berkembang di seluruh wilayah Indonesia. Hal ini tidak disia-siakan oleh para sesepuh Tengger untuk menggali dan mempelajari sejarah nenek moyang dan nilai-nilai tradisi yang pernah ada dan berjaya di zaman Majapahit. Agama yang dianut oleh masyarakat suku Tengger pada waktu itu masih belum jelas, namun orang Tengger mengaku memeluk agama Budha tetapi dalam kenyataan dan ciri-ciri dalam melaksanakan kegiatan keagamaannya tidak menunjukkan ciri sebagai pemeluk agama Budha, bahkan dalam pelaksaaannya lebih menonjol ciri agama Hindu.

Secara jelas dan terbuka, baru pada abad ke-20 para penduduk Tengger berupaya untuk menggali secara mendalam tentang sejarah spritual mereka serta dihubungkan dengan Zaman Majapahit dan keberadaan Hindu seperti sekarang ini. Akhirnya pada tahun 1973, secara resmi pemerintah Indonesia mulai mengadakan pembinaan agama Hindu Dharma bagi orang-orang yang berada di Tengger. Pada tahun 1973, para pini sepuh (golongan tua) suku Tengger di kawasan

${ }^{6}$ Ibid. 
Gunung Bromo, dengan dipimpin bapak Utjil (Sartali), mengadakan urun rembug (musyawarah) secara mufakat di Balai Desa Ngadisari Kecamatan Sukapura Kabupaten Probolinggo. Tujuan diadakannya musyawarah tersebut guna mempersatukan masyarakat suku Tengger. Warga akhirnya menyepakati salam khusus (sapaan) bagi masyarakat Tengger yang berbunyi: Houng Ulum Basuki Langgeng, kurang lebih artinya demikian, "Tuhan tetap memberikan keselamatan/ kemakmuran yang kekal abadi kepada kita”. Salam ini biasanya diucapkan atau digunakan masyarakat Tengger pada awal dan akhir pertemuan resmi serta upacara-upacara tradisional. Suatu sapaan yang khas lokalitasnya dan terbentuk dalam ruang publik yang berhasil didiskursuskan dalam ruang tersebut.

Pada tahun yang sama, agama Hindu Dharma Bali juga mulai berpengaruh di kawasan Tengger. Hal ini dapat dilihat dari pergantian salam agama Hindu Tengger sebagaimana tersebut di atas dengan salam yang baru yang berbunyi Om Swatyastu yang bermakna "semoga anda dalam keadaan baik atas karunia Hyang Widhi” Selain itu, bahwa upacara adat yang dilakukan menunjukan adanya salah satu upacara agama Hindu. Upacara tersebut dikenal dengan upacara Galungan dan beberapa mantra yang biasa dibaca pada setiap upacara adat. ${ }^{7}$

Lebih lanjut Simanhadi menegaskan, saat ini telah diajarkan keimanan terhadap Tuhan Yang Maha Esa berupa Panca Sradha, yaitu (1) percaya kepada sang Hyang Widhi, Tuhan Pencipta Alam; (2) percaya adanya Atma (n), yaitu ruh leluhur atau ruhnya sendiri; (3) percaya adanya Karmapala yaitu hukum sebab akibat. Percaya adanya karmapala merupakan inti ajaran agama Hindu dan agama Budha. Artinya, bahwa semua perbuatan manusia itu pasti terikat pada hukum sebab akibat yang akan dialami oleh manusia baik sekarang maupun pada hidup yang akan datang; (4) percaya kepada Purnabawa atau Reinkarnasi. Kepercayaan ini berasal dari agama Hindu dan agama Budha, bahwa manusia terikat pada hukum hidup berkalikali sesuai dengan Dharma hidup sebelumnya; (5) percaya kepada Moksa atau Sirno, yaitu bahwa jika manusia telah mencapai Moksa, tidak akan terikat kembali pada Purnabawa, mereka berada pada tempat kedamaian abadi.

${ }^{7}$ Simanhadi Widyaprakoso, Masyarakat Tengger..., h. 42. 


\section{B. Aktivitas Upacara Keagamaan 'Lokal': Hari Raya Kasada}

Hari raya kasada adalah hari raya khusus masyarakat Tengger, dan tidak berlaku bagi agama Hindu pada umumnya. Dengan demikian, terdapat lokalitas yang berbeda dengan agama-agama besar. Tahapan-tahapan yang harus dilalui pada Hari Raya Kasada tersebut adalah sebagai berikut: ${ }^{8}$

a. Pengambilan air tirta atau air suci di Gunung Widodaren. Tirta atau air suci ini diambil untuk melakukan ritual, yang dikenal dengan nglukat umat yang bermakna penyucian jiwa masyarakat Tengger di Poten. Tirta itu diambil oleh para dukun dari setiap desa di kawasan Tengger dua atau tiga hari sebelum acara pembukaan Hari Raya Kasada. Pengambilan Tirta itu dilakukan dengan upacara tertentu dan disertai bacaan-bacaan mantra tertentu oleh dukun. Tirta dimasukkan ke dalam botol untuk kemudian digunakan untuk nglukat umat.

b. Pembukaan Hari Raya Kasada, dibuka oleh ketua panitia dan dihadiri pimpinan Parisda lainnya, serta para dukun-dukun dari seluruh desa di kawasan Tengger. Upacara tersebut dihadiri pula oleh para pejabat pemerintah, mulai dari tingkat I Propinsi Jawa Timur dan bahkan kadang-kadang dihadiri oleh Menteri Pariwisata. Acara ini dilakukan di Balai Desa Ngadisari dan sekitarnya. Setelah peresmian, dilanjutkan dengan acara inti berupa pertunjukan Sendratari RaraAnteng danJaka Seger, setelah diramaikan dengan hibuanhiburan yang diikuti oleh berbagai daerah di Jawa Timur. Tempat pertunjukan ini juga sebagai tempat berkumpulnya rombongan peserta upacara dari masing-masing desa yang dipimpin oleh dukun dan isterinya, para legen (sesepuh), dan kaum tua masing-masing desa dengan berpakaian adat, seperti udeng (ikat kepala) coklat, jas hitam, jaret coklat. Dibawa pula ongket yang berisi kembang-kembang, buahbuahan segar, sayur-sayuran yang tumbuh di desanya, seperti kembang pujang, kembang tanah layu, janur, kubis,

${ }^{8}$ Disarikan dari tulisan: Juli Astutik, Makna Ritual Upacara Kasada dalam Perspektif Antropologi, dalam Agama Tradisional, (Yogyakarta: LkiS, 2003), h. 128131. 
kentang, dan wortel. Acara ini diikuti oleh umatnya masingmasing, mereka biasanya membawa bekal, sebab upacara di Poten (lautan pasir) akan berlangsung sampai besok pagi. Peserta upacara Kasada juga berdatangan dari Kabupaten Malang, Pasuruan dan Lumajang, paling sedikit diikuti oleh 6 orang dukun beserta umatnya. Setelah mengikuti upacara pembukaan sekitar jam 23.00, para dukun dengan umatnya secara berkelompok meninggalkan tempat upacara di Balai Desa Ngadisari dan sekitarnya menuju ke Poten tempat upacara ritual Hari Raya Kasada dilaksanakan. Mereka berjalan kaki dari Ngadisari melalui Cemoro Lawang menuju lautan pasir dengan membaca mantra-mantra. Laut Pasir menurut kepercayaan Tengger merupakan tempat yang sangat sakral. Oleh karena itu, urusan keamaan dan pemuka-pemuka adat serta peserta upacara diatur dan ditempatkan di tempat yang telah ditentukan.

c. Upacara ritual Kasada di Poten, dilakukan pada tanggal 15 bulan purnama pada bulan ke-12 (Kasada), menurut perhitungan masyarakat Tengger. Upacara itu dilakukan di lautan pasir atau Poten, sisi utara kaki Gunung Batok, mulai dari jam 02.00 WIB sampai jam 07.00 WIB dengan acara sebagai berikut:

1) Persiapan upacara di mana para dukun, legen dan pinih sepuh adat Tengger mengatur tempat-tempat penting, seperti tempat padmasana, mandala utama, kursi-kursi para dukun, dan mengatur kesempurnaan dwipa, wewangen, dan bija yang akan dibagikan kepada para peserta upacara;

2) Kidung-kidung semacam uyon-uyon diringi gamelan, menyanyikan kidung yang bersifat religius dan pujianpujian antara lain :

Kidung mijil sulastri

Utamane wong arep mamuji

Dadap-dadap tanggap

Yenpita mantepe karya

Kinar suci mesi dipasti

Aja nganti lali 
Dan masih banyak lagi kidung-kidung yang lainnya;

3) Nglukat umat, upacara ini dimaksudkan untuk menyucikan tempat-tempat persembayangan, seperti Padawasana atau tempat dewa-dewa, mandala madya atau tempat para pendeta dan dukun;

4) Pembacaan kitab suci Weda, biasanya pembacaan ini dilakukan secara bergantian oleh pembaca-pembaca yang memiliki suara yang bagus dan indah, termasuk yang baik bacaannya. Salah satu doa yang dibaca adalah doa syukur seperti berikut;

Om Dewa Suksama pornama acintyaya

Nama swaha sarwa karya prasidanthan

Om santhi, santhi, santhi, om.

(Ya Tuhan dalam wujud prama acitya. Yang Maha gaib, atas anugrah-Mulah, maka pekerjaan ini berhasil dengan baik, damai di dunia, damai selamanya);

5) Pembacaan sejarah Kasada, perkawinan Rara Anteng dan Jaka Seger. Diceritakan secara bertutur, dalam perkawinan Rara Anteng dan Jaka Seger yang telah lama kawin, namun mereka juga belum mendapatkan anak. Upaya untuk mendapatkan anak dilakukan dengan bersemedi di Gunung Pananjakan dengan memohon kepada Dewa agar dikaruniai anak. Dalam semedi itu keduanya berjanji, jika mereka dikarunai anak, maka anak yang terakhir akan dikorbankan kepada Dewadewa di kawasan Gunung Bromo. Upaya itu rupanya mendatangkan hasil. Akhirnya pasangan itu dikarunia 25 anak. Maka, sesuai dengan janji Rara Anteng dan Jaka Seger bersama 25 anaknya pergi ke tepi kawah Gunung Bromo untuk melaksanakan janjinya. Namun, hanya anaknya yang terakhir yang ke-25 yang bernama Raden Kusuma yang rela berkorban dan masuk ke dalam bawah Gunung Bromo dalam keadaan gelap gulita dan petir menyambar. Setelah keadaan mulai reda dan tenang terdengar suara gaib dari kawah Gunung Bromo yang berbunyi sebagai berikut, sebagaimana yang dituturkan oleh salah seorang dukun yang ditemui: 
He bapak karo ibu lan dulur-dulur kabeh

Reang wis urip seneng ana kene

Iling nyang pesane reang

Saban rembulan handadari wektu Kasada

Reang njaluk tandur tuwuhe lemah kene

Muga-muga slamet sak turunan-turunanmu kabeh

Wis sak mono wae reang;

6) Nglukat umat, acara ini dilakukan untuk membersihkan jiwa umat (Suku Tengger) dari jiwa yang kotor dengan: (a) pembagian bija yang ditempelkan di bagian muka, jika kelebihan bija sebaiknya jangan di buang tetapi lebih baik dimakan, (b) pemberian wewangen atau bunga yang diletakkan di telinga sebelah kanan, (c) membakar dwipa di Perapen, dan (d) memercikan tirta di kepala dan muka umat. Setelah semua peserta upacara mendapatkan itu semua, maka dilakukan persembahyangan;

7) Muspa atau persembahyangan, upacara persembahyangan dipimpin oleh Pinandita dan dibantu oleh para pemuka dengan mengapitkan kedua tangan dan di tengahnya diletakkan bunga kemudian diangkat dengan membaca doa sesuai dengan maksud masing-masing, baik sebagai dukun maupun sebagai masyarakat biasa. Dalam acara ini, ada juga doa bersama yang dipimpin oleh Pinandita dengan membaca mantra yang sangat panjang. Ada juga doa khusus menurut keinginan desa masing-masing serta ada juga doa yang dilakukan sendirisendiri untuk meminta keselamatan serta permintaan khusus. Doa-doa yang dibaca dalam persembahyangan tersebut sebagian ada yang melakukannya dengan Puspa Puyung (kosong), ada juga dengan Puspa putih, Puspa merah dan bahkan ada yang dengan Puspa campuran (putih, merah, dan kuning). Jenis atau macam doa yang dibaca dalam persembahyangan tersebut, yang paling penting dan sering dibaca ialah doa untuk tiga waktu, yaitu waktu pukul 06.00 pagi hari, waktu pukul 12.00 siang hari, dan waktu pukul 18.00 sore hari. Doa tersebut berbunyi sebagai berikut: 
Mantra Trisandiya:

- Om Bhur tat savitur varenyam bhargo davasya dhimahi dhiyojo pracodayat

- Om Narayanna evedam sarvan yad butham yac ca bahvyam niskalanko niranjanu nilvikalpo suddo deva eko Narayano na dvitiyo'sti kascit

(Tuhan adalah Bhur Swah, kita memusatkan pikiran pada kecemerlangan dan kemulyaan Hyang Widhi semoga ia berikan semangat pikiran kita)

- Om tvam sivah tvammahadevah isyarah paramevarah brahma vinusca purusca parikir titah

(Ya Tuhan Narayana, adalah semua ini apa yang ada dan apa yang akan ada bebas dari noda, bebas dari kotoran, bebas dari perubahan, tak dapat digambarkan, sucilah dewa Narayana. Ia hanya satu tidak ada yang dua)

- Om papo ham papakarmaham papatma papasambhavah mampundarikaksa sucih

(Ya Tuhan, engkau dipanggil Syiwa, Mahadewa, Iswara, Parameswara, Brahma, Wisnu, Rudra, dan Parusa).

- Om ksamasva mam mahadeva sarvaprani hitankara mam macosarva papeb yah payasva sada siva (Ya Tuhan, hamba ini papa, lindungilah hamba, Hyang Widhi sucikanlah jiwa dan raga hamba).

- Om ksantavyah kayiko dosah ksantavyo manaso dosan tat paramadat ksamava mam,

(Ya Tuhan, ampunilah hamba Hyang Widhi, yang memberikan kepada semua mahkluk, bebaskanlah hamba dari semua dosa, lindungilah hamba, oh Hyang Widhi).

- Om Santhi, Santhi, Santhi Om

(Ya Tuhan, ampunilah dosa anggota badan hamba, ampunilah dosa pikiran hamba, ampunilah hamba dari kelahiran hamba, ya Tuhan, semoga damai, damai, damai selamanya).

- doa sehari-hari menurut agama Hindu; 
8) Dao pasca sembah, doa ini sangat penting dibacakan pada Hari Raya Kasada yang biasanya dinamakan juga Keramaning Sembah yang terdiri dari lima mantra, yang artinya sebagai berikut :

(1).YaTuhan, Atma ataujiwa dan kebenaran, bersihkanlah hamba. (2). Ya Tuhan sinar Hyang Surya Yang Maha Hebat, engkau bersinar merah, hamba memuja engkau. Hyang Surya yang bersinar di tengah-tengah teratai putih hamba memuja engkau yang menciptakan matahari berkilauan. (3). Ya Tuhan, kepada Dewata yang bersemayam pada tempat yang luhur, kepada Hyang siwa yang ada di mana-mana, kepada Dewata yang bersemayam di tempat duduk bunga teratai di suatu tempat, kepada Arahanarisvari hamba memuja. (4). Ya Tuhan, engkau yang menarik hati, pemberi anugerah, anugerah pemberian Dewata, pujaan segala pujaan, hamba memuja-Mu sebagai pemberi segala anugerah. Kemaha sucian pada Dewa dan Dewi berwujud zat yang suci, kebahagiaan, kesempurnaan, panjang umur, bebas dari rintangan, kegembiraan dan kemajuan ruhani dan jasmani. (5). Ya Tuhan, hamba memuja Engkau Dewata yang tidak terpikirkan, Maha Tinggi dan Maha gaib, Ya Tuhan, anugerahkanlah pada kedamaian, damai, damai, Ya Tuhan.

9) Pemilihan Calon Dukun

Pemilihan atau penetapan seseorang menjadi dukun di masyarakat Tengger harus memenuhi syaratsyarat sebagai berikut: a) pernah menjadi legen selama beberapa tahun, b) hafal sebagian besar mantra-mantra yang dibacakan pada bermacam-macam jenis upacara adat, c) telah memenuhi sebagian syarat lain yang harus dipenuhi oleh pemangku adat Tengger, dan d) seseorang dapat diangkat menjadi calon dukun, apabila di tahun sebelumnya (dalam 44 hari sebelum Kasada) di desa tempat tinggal calon dukun tersebut tidak ada orang meninggal dunia. Calon dukun tersebut hanya diundang menghadiri upacara di Poten. Penetapan menjadi dukun dilakukan dengan upacara sakral pada 
waktu Hari Raya Kasada dengan disaksikan oleh para pejabat, pemimpin Parisada dan para pemangku adat, dan sebagian masyarakat Tengger yang hadir pada waktu itu. Calon dukun yang akan dilantik menjadi dukun harus memakai pakaian adat, bisanya berupa hem putih, jas hitam, udeng coklat, selempang kuning yang dipasang dibagian dada sebagai tanda menjadi dukun resmi

10) Acara lelabuhan sesajen di kawah Gunung Bromo Acara ini dilakukan setelah prosesi persembahyangan di Poten, di Pura Agung di tengah lautan pasir di kaki Gunung Bromo sekitar pukul 06.00 pagi hari. Acara sesaji lelabuh sesajen (membuang sesajen di kawah Gunung Bromo) diatur dengan cara berbaris dengan berjalan kaki dari Poten menuju ke kawah Gunung Bromo secara berkelompok sesuai rombonganya masingmasing dari setiap desa. Posisinya sebagai berikut: (a) rombongan pertama para pejabat pemerintah bersama pejabat Parisada Hindu Dharma, (b) rombongan kedua adalah rombongan para dukun yang datang dari empat kabupaten (Probolinggo, Malang, Pasuruan, dan Lumajang), (c) rombongan ketiga adalah pembawa onkek yang dibawa oleh para legen dan sebagian peserta upacara, dan (d) rombongan keempat adalah kelompok dari tiap-tiap empat kabupaten tersebut. Mereka berjalan secara teratur sampai ke mulut kawah Gunung Bromo, kemudian membuang sesajen yang di bawa tersebut dengan membaca mantra atau doa, sesuai dengan niatnya masing-masing;

11) Slametan (pepujan) desa, akhir dari peringatan Hari Raya Kasada biasanya ditandai dengan upacara slametan desa masing-masing sehari sesudah upacara di Poten. Slametan desa ini biasanya diikuti semua warga yang dilaksanakan di Sanggar atau Pura masing-masing desa atau bisa juga di Balai Desa masing-masing desa. Dalam upacara Slametan desa ini, pembacaan doa atau mantra-mantra dipimpin oleh dukun dan dibantu para Legen serta sesepuh desa, sedangkan sambutan diberikan Kepala 
Desa. Isi sambutannya berkenaan dengan pembinaan dan pembangunan di desa masing-masing.

\section{C. “Yang Sakral” dan "Yang Profan” dalam Upacara Kasada}

Inti dari agama (kepercayaan) dalam pandangan Mircea Eliade adalah dialektika (hubungan timbal balik antara yang sakral dan yang profan. ${ }^{9}$ Manusia beragama selalu berusaha hidup dalam dunia yang sakral atau di tengah benda-benda yang suci. Hal itu sama dengan masalah to be or not to be. "Yang sakral itu merupakan kekuatan bagi dia. "Yang sakral" itu sama dengan syarat untuk berada atau bereksistensi. Pertentangan antara "yang sakral" dengan "yang profan" sesungguhnya dapat disetarakan dengan "yang real" dan "yang tidak real", seperti dalam problem metafisika. Sebetulnya usaha hidup relegius sama saja dengan usaha "berada" atau bereksistensi, usaha untuk bereksistensi dalam mengambil bagian dalam realitas, melengkapi diri dengan kekuatan. ${ }^{10}$ Upacara Kasada merupakan bentuk eksistensial masyarakat tengger, usaha 'mengadakan' diri mereka dengan tidak bersifat dualistik ketika berhadapan dengan alam. Tetapi merupakan bentuk eksistensial manusia manunggal, menyatu dalam keharmonisan dengan alam dan yang ghaib.

\section{Sakralisasi Alam dan Ruang}

Banyak hierofani berkaitan dengan alam atau dengan kejadian dengan alam (guntur, gempa bumi, gunung meletus dan sebagainya). Hampir apa saja yang ada di alam bisa menjadi simbol relegius. Langit, matahari, batu serta benda-benda lainnya bisa menjadi hierofani karen menjadi simbol relegius.

Sementara penghayatan mengenai ruang sakral memungkinkan pendasaran dunia (kosmisasi). Sebab ruang tidak

9Sakralitas adalah lawan profanitas. Bandingkan etimologi kata "profan" (pro-fanum): apa yang terletak di depan atau di luar tempat suci.

${ }^{10}$ K. Bertens, "Yang Sakral dan Yang Profan dalam Penghayatan Tradisional Homo Religious Menurut Mircea Eliade” Ulumul Qur'an, h. 47. Kekuatan dalam konteks masyarakat tradisional lebih dimaknai kekuatan dalam arti yang bersifat 'melampaui' batas nalar dalam arti tertentu. Meskipun sesunguhnya term pelampauan atas nalar nalar ini bukan berarti tidak bisa dinalar, tapi mungkin masih bersifat belum bisa dinalar. 
homogen, manusia bisa membentuk dunia di mana ia dapat hidup. Karena dengan itu diberikan suatu titik teguh, yang bisa menjadi poros tetap (axis mundi). Dalam masyarakat kuno, orang mau mendirikan desa baru, atau membangun rumah baru, terlebih dahulu harus mendapatkan titik teguh semacam itu. Hal tersebut mempunyai makna eksistensi bagi orang beragama. Ia tidak akan bisa diam di sebuah tempat tersebut kalau tidak ada titik teguh serupa. ${ }^{11}$

Kebanyakan suku bangsa di Indonesia dan juga di beberapa negara mempunyai tempat yang disakralkan di dalam rumah, tepatnya berada di perapian atau dapur di mana orang tidak boleh berbuat sembarangan. Tempat upacara ini bisa juga terletak di suatu tempat umum, seperti di pusat desa, umumnya tempat tersebut digunakan untuk upacara-upacara yang melibatkan partisipasi seluruh warga masyarakat dan tempat tersebut juga dianggap sebagai pusat dari aktivitas desa. Kecuali tempat tersebut, masih banyak terdapat tempat yang dianggap sakral, seperti di tengah ladang, sawah, pantai laut, atau bahkan lautan pasir Gunung Bromo atau Poten (dalam istilah suku Tengger).

Tempat upacara yang sakral biasanya merupakan suatu tempat yang dikhususkan dan tidak boleh didatangi oleh orang yang tidak berkepentingan. Bahkan orang yang mempunyai kepentingan pun tidak boleh sembarangan berbuat di tempat upacara tersebut. Setiap orang dari masyarakat Tengger harus berhati-hati dan memperhatikan berbagai macam aturan, larangan ataupun pantangan. Pada masyarakat Tengger tempat upacara ini biasanya dilakukan di sekitar Gunung Bromo, Sanggar Pemujaan, Gua Widodaren (tempat pengambilan air suci), Poten (di sekitar Gunung Batok), dan masih banyak tempat upacara yang disakralkan bagi masyarakat suku Tengger.

Pelaksanaan upacara ritual Kasada pada masyarakat Tengger ini dipusatkan di Balai Desa Ngadisari, di mana tempat tersebut sebagai tempat transit bagi masyarakat Tengger yang bermukim di daerah lain yang agak jauh dari Gunung Bromo (seperti dari Kabupaten Probolinggo, Malang, Lumajang, dan Pasuruan). Untuk selanjutnya upacara ritual tersebut dilakukan dengan berjalan kaki

${ }^{11}$ Ibid., h. 48 
dari Ngadisari melalui Cemoro Lawang menuju lautan pasir (Poten) dengan membaca mantra-mantra. Lautan pasir menurut kepercayaan masyarakat Tengger merupakan tempatyang sangat sakral.Pemilihan tempat ini bukan sekedar agar upacara bisa dilaksanakan dengan leluasa, tetapi lebih dari itu adalah masyarakat Tengger meyakini tempat-tempat tersebut mempunyai poros yang tetap.

Peristiwa hierofani juga nampak kental mewarnai upacara tersebut di atas. Peristiwa penampakan yang suci ini terjadi kapan saja, pagi, siang, sore, maupun malam dan lewat apa saja, bisa melalui medium manusia, hewan, tumbuh-tumbuhan dan bendabenda dunia lainnya. Dengan menampakkan diri, Yang Suci tak lagi menjadi sesuatu yang absolut, kini Ia terbatas dalam bendabenda. Dan karena benda-benda tersebut telah menjadi medium bagi yang suci, maka benda-benda tersebut ikut tersucikan dan menjadi sakral. Batu itu lalu menjadi suci, lalu di anggap tabu, dan di mintai pertolongan. Batu tersebut setiap saat lalu diziarahi, menjadi medium untuk mengantarkan manusia 'berkomunikasi' dengan yang sakral. Batu adalah hierafani yang dianggap tanpa ruang, tanpa waktu, dan tanpa perubahan apapun. Karena itu, dia melambangkan kemuliaan, kekuasaan dan keabadian yang berasal dari 'yang ilahi”" 12 .

\section{Sakralitas Waktu}

Sebagaimana dengan ruang yang bersifat homogen, waktu juga demikian. Ada waktu yang sakral adapula waktu yang profan. Waktu sakral berlangsung bila manusia merayakan pesta-pesta perayaan yang bersifat periodik. Waktu profan adalah waktu dimana peristiwa-peristiwa sehari-hari berlangsung. Tak ada kontinuitas antara dua jenis waktu. Tetapi dengan ritus manusia bisa beralih dari waktu biasa menuju waktu yang kudus.

Perbedaan hakiki antara kedua jenis waktu tersebut adalah bahwa waktu sakral menurut kodratnya adalah reversibel, dapat dibalikkan, dalam arti bahwa masa lampau bisa dihadirkan kembali. Sedangkan ciri khas waktu biasa tak mungkin bisa terulang kembali dan telah lewat selama-lamanya. Waktu sakral adalah waktu yang berlangsung dalam mitos-mitos. Waktu di mana berlangsung

${ }^{12}$ Ibid., h. 48. 
peristiwa-peristiwa yang diceritakan mitos-mitos, seakan-akan suatu "waktu sekarang" yang abadi, yang selalu dapat dihubungi dan dihadirkan kembali. ${ }^{13}$

Upacara Kasada adalah tak lain dari penciptaan dunia oleh dewa-dewa, artinya tak lain dari menghadirkan penciptaan dunia. Waktu dalam upaca kasada tersebut menandakan bahwa di sana berarti keluar dari waktu yang profan dan masuk ke dalam waktu yang sakral (waktu mitis) yang dhadirkan dalam pesta tersebut. Di samping itu, saat pelaksanaan upacara biasanya dirasakan sebagai saat-saat yang "genting" dan penuh keheningan, bahkan beresiko karena penuh dengan bahaya gaib.

\section{Refleksi Metafisik}

\section{Melacak Yang Transenden}

Transendensi adalah dasar eksistensi, sebab eksistensi tidak mempunyai dasar dalam dirinya sendiri. Baru karena hubungannya dengan Transendensi maka manusia menjadi eksistensi yang sungguh-sungguh; eksistensi baru mendapatkan kesadaran sebenarnya tentang keterbatasannya dalam Transendensi. ${ }^{14}$

Walaupun Transendensi seolah-olah berbicara melalui dunia tetapi Transendensi tidak dapat dibatasi oleh kategori-kategori, tidak pula hadir sebagai realitas empiris. Pengalaman eksistensial tentang Transendensi tidak dapat dirumuskan dengan memuaskan, karena Transendensi itu merupakan realitas yang tidak terberikan, tidak dapat dikenal. Oleh kerena itu kita tidak sanggup memikirkan Transendensi secara objektif (sebagai objek), maka manusia hanya dapat berbicara tentang pengalaman Transendensi secara simbolis ${ }^{15}$.

Transendensi hanya dapat dikenal melalui chiffre-chiffre atau "tulisan-tulisan sandi". Istilah chiffre dalam bahasa Inggris chipher, berasal dari bahasa Arab Sifr berarti "nol" atau "kekosongan". Dalam makna terminologi chiffre berarti simbol-simbol atau tulisan yang

${ }^{13}$ Ibid., h. 49

${ }^{14}$ Joko Siswanto, Metafisika Sistematik, (Yogyakarta: Taman Pustaka Kristen, 2004), h. 82

${ }^{15}$ Ibid., Lihat. Frederick Sontaq, Pengantar Metafisika, (Yogyakarta: Pustaka Pelajar, 2001), h. 103 
menunjukkan pada Transendensi. ${ }^{16}$ Tulisan-tulisan sandi yang berarti simbol adalah adalah yang mengentarai eksistensi dan Transendensi. Simbol yang memperantarai "naskah" yang "ditulis" oleh Allah, dan yang "dibaca” manusia. Pembacaan terhadap naskah tersebut disebut "metafisika”. Ia dianggap juga sebagai "Transendensi yang immanen", "kehadiran Transendensi tanpa isi". Kehadiran dan ketidakhadiran menjadi satu di dalamnya. Tidak ada sesuatu apapun yang tidak dapat menjadi chiffre; alam, sejarah, kesadaran murni, manusia sebagai pribadi, kesatuan manusia dengan alamnya, kebebasan. Di antaranya terdapat bidang-bidang tertentu yang berbicara sangat jelas sebagai chiffre, seperti semua situasi batas, kebebasan, seni dan cinta ${ }^{17}$.

Bagi Jaspers, metafisika mempunyai tempat yang istimewa karena metafisika merupakan sistem spekulatif yang menjawab pertanyaan-pertanyaan paling dalam tentang Allah, manusia dan dunia, itu kini tidak mungkin lagi. Yang masih mungkin dipertanyakan dalam problem metafisika sebagai "jalan mistik dalam pemikiran". Metafisika yang "membaca" seluruh kenyataan sebagai buku yang ditulis Allah, dan yang hanya terdiri dari simbolsimbol ${ }^{18}$.

Upacara ritual ini diyakini masyarakat setempat sebagai upacara yang memiliki nilai sakral yang sangat penting bagi kehidupan mereka, sehingga upacara ritual ini tidak hanya dilaksanakan oleh mereka yang beragama Hindu, namun juga yang beragama Islam. Peringatan upacara ritual "Kasada” yang sakral, unik serta sarat dengan nilai religi yang sangat tinggi ini telah dikenal oleh masyarakat luas, bahkan perkembangan terakhir ini momen tersebut dijadikan sebagai objek wisata, baik bagi turis domestik maupun mancanegara.

Dalam pandangan Eliade, manusia dalam homo religious adalah tipe manusia yang hidup dalam suatu alam yang sakral, penuh dengan nilai-nilai religius dan dapat menikmati sakralitas

${ }^{16}$ Harry Hamersma, "Eksistensi dan Transendensi dalam Metafisika Karl Jaspers”, dalam Manusia Multidimensional: Sebuah Renungan Filsafat, M. Sastrapratedja (ed.). (Jakarta: Gramedia, 1983), h. 55.

${ }^{17}$ Ibid., h. 53

${ }^{18}$ Ibid., h. 53-54 
yang ada dan tampak pada alam semesta, alam materi, alam tumbuh-tumbuhan, alam binatang dan manusia. Pengalaman dan penghayatan akan yang sakral ini lalu mempengaruhi, membentuk, dan ikut menentukan corak serta cara hidupnya.

Dalam konsepsi homo religious, dunia tidak hanya terdiri dari satu tingkat, tetapi terbangun atas dua dunia yakni: 'dunia bawah' yang dihuni sekarang ini, dan 'dunia atas' yang terdiri dari dunia para dewa, nenek moyang dan para pahlawan purba. Kedua dunia ini berhubungan satu sama lain oleh sebuah poros, axis mundi, poros dunia. Keyakinan akan adanya 'dunia atas' tersebut membuat homo religious rindu akan keberadaan dunia atas tersebut, dan setiap kali merindukannya ia harus melakukan ritual upacara-upacara yang sesuai dengan penciptaannya. ${ }^{19}$

Ironisnya, dunia seperti sekarang ini bukan lagi dunia yang murni, seperti pada saat baru lahir atau diciptakan oleh para dewa. Dunia sekarang ini telah jatuh, sudah rusak, makin bertambah umur dan menuju kehancuran. Karena itulah dunia ini setiap kali harus diperbaharui, dibangun dan diciptakan kembali. Kosmogoni merupakan model percontohan untuk segala macam tindakan kreatif dalam segala bidang pembaharuan, pembangunan dan penciptaan kembali. Maka pembaharuan dan penciptaan dunia dilakukan dengan upacara-upacara yang pada dasarnya merupakan tindak peragaan atau pengulangan kembali mitos kosmos ${ }^{20}$.

Simbolisme dan upacara-upacara yang berhubungan dengan perpindahan itu mengungkapkan suatu gagasan mengenai situasi hidup manusia di dunia ini. Sewaktu dilahirkan di dunia, manusia belum sempurna adanya. Untuk menjadi sempurna, manusia harus mengalami berbagai upacara perpindahan, upacara inisiasi, atau rite de passage. Dengan upacara itu manusia dipindahkan dari suatu tingkat hidup yang satu ke tingkat hidup yang lain. Dengan kata lain, manusia sempurna itu tidak terjadi dengan sendirinya melainkan harus dibuat, dibentuk. Upacara perpindahan, di mana manusia dinaikkan tingkat kehidupannya ini, bukan berasal dari mereka

${ }^{19}$ Mangunhardjono, "Homo Religious menurut Mircea Aliade", dalam Manusia Multidimensional: Sebuah Renungan Filsafat, M. Sastrapratedja (ed.). (Jakarta: Gramedia, 1983), h. 39.

${ }^{20} \mathrm{Ibid}$. 
sendiri, melainkan dari nenek moyang, sebagai barang warisan yang berharga $^{21}$.

Dalam pandangan Franz Magnis Suseno, berbicara tentang pandangan masyarakat Jawa bukanlah dalam pengertian agama dalam arti sempit (seperti pengertian yang selama ini berkembang di masyarakat Barat dan dunia pada umumnya). Menurutnya, pandangan dunia Jawa menyangkut berbagai ritus-ritus, dalam menaman padi dan perayaan panenan, tentang kehidupan keluarga dan seni tari-tarian, tentang mistik dan susunan desa. Pandangan dunia orang Jawa digolongkannya menjadi empat lingkaran.

Salah satu lingkaran adalah bersifat ekstrovet, yakni sikap terhadap dunia luar yang yang alami dengan kesatuan numinus (pengalaman spiritual) antara alam, masyarakat dan alam adi kodrati. Pengalaman ini terejawantah dalam berbagai ritus, tanpa refleksi eksplisit terhadap dimensi batin sendiri. Kesatuan masyarakat, alam dan alam adi kodrati sebetulnya terungkap dari kepercayaan bahwa setiap kejadian yang bersifat empiris selalu berkaitan dengan hal yang adi kodrati atau metaempiris. Kesatuan masyarakat, alam dan adi kodrati ini diwujudkan dengan sikap hormat pada nenek moyang, melakukan ritual sesaji, slametan dan berbagai ritus lainnya. Karena setiap kejadian di alam empiris ini selalu terkait dengan alam adi kodrati, maka sesorang dalam perilakunya harus memperhatikan dan melakukan ritus-ritus tersebut sebagai upaya untuk menyelematkan diirinya dari berbagai kejadian yang tidak diinginkan. Lebih dari itu, agar segenap tindakannya terkontrol dengan baik, maka diciptakannya sistem klasifikasi tentang arah, tentang alam, dan kosmos. Dalam konteks inilah kemudian dikenal Buku Primbon, sebuah kitab yang berisi petunjuk-petujuk yang baik dalam menjalankan aktivitas duniawi. ${ }^{22}$ Buku ini kemudian dijadikan rujukan untuk pengobatan penyakit, penentuan harihari yang baik, dan berbagai hal lainnya yang berhubungan dengan dunia adi kodrati.

Dengan demikian, Upacara Kasada menjadi sangat penting keberadaannya bagi masyarakat Tengger. Upacara ini terdiri dari

${ }^{21}$ Ibid., h. 41.

${ }^{22}$ Frans Magnis Suseno, Etika Jawa: Sebuah Analisa Falsafi tentang Kebijaksanaan Hidup Jawa, (Jakarta: Gramedia, 1985), h. 85-89. 
suatu deretan ritus dan ajaran-ajaran lisan. Tujuannya mengubah status religius dan sosial seseorang. Dengan menjalani berbagai upacara ini manusia mengalami perubahan eksistensial. Ia dilahirkan kembali menjadi manusia baru, manusia yang lain daripada sebelumnya. Oleh karena itu, masyarakat Tengger selalu mengadakan upacara untuk menghadapi tahap baru dalam hidupnya. Misalnya, kelahiran, pernikahan, dan meninggal dunia, atau bahkan mengalami status perubahan religius dari masyarakat biasa menjadi tokoh spiritual atau dukun. Dengan menjalani upacara tersebut, juga terjadi semacam peralihan status. Dari status natural ke status religius dan kultural. Dalam relasinya dengan sosial, upacara tersebut mampu mengantar sosok individu menjadi manusia yang bertangung jawab pada lingkungan, masyarakat dan bahkan tradisi nenek moyangnya.

2. Simbol Kearifan Dukun

Dalam film Dances With Wolf yang dibintangi Kebin Costner digambarkan ketika seorang kepala suku kebingungan mengambil sebuah keputusan yang berkaitan dengan kemaslahatan masyarakat banyak. Jalan yang kemudian ditempuh adalah meminta advice (nasihat) kapada dukun (penasihat spiritual) yang disaksikan oleh orang-orang penting dari suku (Sioux) di daerah tersebut. Ketika nasehat telah diberikan maka serta merta yang hadir akan mengamininya. Peryataan tunduk dan patuh kepada dukun bukan karena sifat otoriternya, karena dukun adalah simbol kebijaksanaan yang mempunyai kewenangan untuk itu. Sikap tunduk patuh semacam itu tidak bisa dilepaskan dari kharisma yang terpancar dari seorang dukun atau ketua adat. Dengan kata lain, ada wewenang yang bersifat karismatik pada diri dukun atau kepala adat.

Wewenang kharismatik pada dasarnya merupakan wewenang yang bertumpu pada kharisma, yaitu suatu kemampuan khusus yang ada pada diri seseorang. Kemampuan khusus tadi melekat pada orang tersebut karena anugerah dari Tuhan yang Maha Esa. Orang-orang disekitarnya mengakui bahwa adanya kemampuan yang dimilki atas dasar kepercayaan dan pemujaan, karena mereka menganggap bahwa sumber kemampuan tersebut adalah seseuatu yang berada di atas kemampuan manusia pada umumnya. Sebagai seorang dukun yang mampu memusatkan suatu takaran kakuatan 
kosmis yang besar dalam dirinya sendiri. Sumber kepercayaan itu muncul karena pernah terbukti manfaat dan kegunaannya bagi masyarakat.

Demikian pula yang tergambar dalam prototipe dukun (ketua adat) di Masyarakat Tengger. Untuk menjadi seorang dukun harus memenuhi kreteria tertentu antara lain: a) pernah menjadi legen selama beberapa tahun, b) hafal sebagian besar mantra-mantra yang dibacakan pada bermacam-macam jenis upacara adat, c) telah memenuhi sebagian syarat lain yang harus dipenuhi oleh pemangku adat tengger, dan d) seseorang dapat diangkat menjadi calon dukun, apabila di tahun sebelumnya (dalam 44 hari sebelum Kasada) di desa tempat tinggal calan dukun tersebut ada orang meninggal dunia. Penetapan menjadi dukun dilakukan dengan upacara sakral pada waktu Hari raya Kasada dengan disaksikan oleh para pejabat, pemimpin parisada dan para pemangku adat dan sebagian masyarakat Hindu Tengger yang hadir pada waktu itu ${ }^{23}$.

Dengan kreteria yang begitu ketat bisa dipahami bahwa dukun adalah tokoh adat yang sangat dihormati dan berkharisma. Karisma yang dimilki oleh seseorang dukun berimplikasi pada proses internalisasi nilai tradisi yang lebih mudah. Ini bisa terjadi karena interaksi sosial berlangsung dengan kekuatan karisma maka yang dominan adalah pengaruh sugesti dari ketua adat. Proses sugesti bisa terjadi karena kelompok masyarakat menganggap apapun yang dikatakan oleh ketua adat adalah sebuah kebenaran yang harus diamini.

Para pemuka upacara keagamaan dalam berbagai macam religi dari berbagai macam suku bangsa di dunia biasanya dapat dibagi ke dalam 3 golongan, yaitu (1) Pendeta, (2) Dukun, dan (3) Syaman. Dalam upacara ritual Kasada ini pemuka upacara keagamaan dilaksanakan oleh dukun yang dibantu oleh para legen, yang diikuti oleh: a). Para dukun. b). Masyarakat suku Tengger yang telah menyebar di 4 Kabupaten: Probolinggo, Malang, Pasuruan, dan Lumajang.

Para pelaku tersebut adalah pemuka agama selaku pemimpin dan diikuti oleh orang-orang yang sekeyakinan.

${ }^{23}$ A. Malik Thaha, Tren Pluralisme Agama, (Jakarta: GIP, 2005), h. 70. 
Dibutuhkannya pemimpin upacara dalam suatu kegiatan ritus agar kegiatan tersebut dapat berjalan sesuai tujuan yang akan dicapai, pemimpin juga berfungsi sebagai mediator yang dianggap mampu menghubungkan antara alam gaib dengan masyarakat pengikutnya. Karena kegiatan ritus ini dianggap sakral, di mana salah satu akibatnya jika tidak dihadapi dengan hati-hati dapat menimbulkan bahaya terhadap diri seseorang, maka petunjuk dan arahan pemuka agama atau pemimpin kegiatan ritus sangat besar pengaruhnya.

Meskipun arus derasnya perubahan sosial terus menghantam masyarakat Tengger, yang prosesnya terjadi melalui perkembangan pariwisata, namun upaya menjaga kelestarian berbagai budaya dan tradisi juga dilakukan juga dengan pelembagaan secara formal melalui aparatur pemerintah desa. Maka tidak heran kemudian dalam proses pemilihan desan bukan hanya persoalan kemampuan manajemen kepemimpinan modern semata, tetapi bagaimana sosok kepala desa yang dipilihnya adalah sosok yang kharismatik, utamanya mampu menjaga kearifan-kearifan lokal yang tela turun temurun diwarisi hingga generasi sekarang.

3. Eksistensi Mitos Rara Anteng dan Jaka Tengger

Kebenaran tentang sesuatu realitas (being) bukanlah masalah kesesuaian antara pemahaman atau konsep atau esensi dan realitas objektif atau thing in itself, melainkan penyingkapan realitas tersebut. Satu-satunya media bagi penyingkapan thing in itself itu adalah eksistensi manusia itu sendiri sebagai knower, interpreter, atau subjek yang mengetahui, membicarakan dan menyingingkapkan. Senyatanya, manusia dalam menyingkapkan dan memahami sesuatu tidak bisa melepaskan dari faktisitas eksistensialnya, dari nilai-nilai miliu yang melingkupinya. Makna tentang ada selalu hanya bisa dimengerti dan diinterpretasikan melalui eksistensi manusia. Oleh karena itu, hermeneutika tidak lebih dari suatu penafsiran diri manusia itu sendiri. Kefaktaan ini menunjukkan bahwa ada selalu di dalam ruang waktu, dan kefaktaan inilah yang disebut Heidegger dengan Dasein. ${ }^{24}$ Sedangkan Gadamer menggambarkan kefaktaan ini dengan istilah Vorurteil, Jadi, hermeneutika eksistensial menegaskan

\footnotetext{
${ }^{24}$ Bandingkan dengan: Martin Heidegger, Being and Time, terj. J. Marquairie, et-al. (New York: Harper \& Row, 1962), h. 24-49.
} 
bahwa upaya memahami dan menafsirkan sesuatu tidak bisa dilepaskan dari eksistensi manusia atau ruang waktu manusia yang sedang mengetahui.

Secara tradisional, Being atau "ada" dimengerti sebagai tidak memiliki batas-batas waktu dan ruang. Pemahaman being dalam arti ini berlangsung lama sejak filsafat Yunani yang tergambar dalam perdebatan para ahli metafisika, kemudian masuk ke periode filsafat abad tengah, sampai era modern, era filsafat Enlightenment. Bagi Heidegger, "ada" dalam pengertian tersebut di atas menjadi sesuatu yang tidak mungkin, karena bagaimanapun "ada" selalu terkait dengan "waktu”, "Ada" selalu dimaknai oleh manusia dalam konteks ruang dan waktu tertentu. Bagi Heidegger, seperti ditulis oleh Chatterjee: "man's being is situated, situated in time and place" ${ }^{25}$ (keberadaan manusia disituasikan, disituasikan dalam ruang dan waktu). Dengan kata lain, keberadaan manusia itu selalu situasional. Keberadaan manusia inilah yang menentukan "ada", bukan "ada" yang menentukan manusia. Keberadaan manusia yang situasional inilah yang melahirkan suatu pemahaman tertentu, dan perbedaan situasilah yang menimbulkan perbedaan pemahaman. Oleh karena itu, "ada" bergantung pada faktisitas eksistensial manusia, bukan sebaliknya.

Man's being there menunjukkan bahwa eksistensi manusia selalu bersifat thrown into a world (terlempar ke dalam suatu dunia). Dunia di sini berarti suatu ruang-waktu, situasi, lingkungan, konteks sosio-politis-kultural-filosofis religius atau mudahnya suatu tradisi tertentu. Hal ini secara konkret bisa dilihat dengan cara menyadari keberadaan kita masing-masing. Misalnya kita dilahirkan dalam keluarga muslim taat tertentu, dalam lingkungan sosial atau tradisi Islami tertentu pula, maka cara kita mengetahui sesuatu khususnya lagi tentang keislaman selalu berangkat dari nilai-nilai, prinsip-prinsip, kepercayaan-kepercayaan, pandanganpandangan yang diberikan oleh tradisi di dalam mana kita hidup, dibentuk dan dipengaruhi. Ketersituasian kita dalam tradisi inilah yang merupakan tempat dari mana kita memperoleh warisan pengetahuan, sikap-sikap, pandangan-pandangan, dan

\footnotetext{
${ }^{25}$ Margaret Chatterjee, The Existentialist Outlook, (New Delhi: Orient Longman Ltd., 1973), h. 131.
} 
kepercayaan-kepercayaan, dan merupakan tempat keterbukaan awal kita mengetahui dan memahami dunia lain.

Dalam konsepsi Heidegger seperti itu berarti dia menganggap persepsi-persepsi a priori faktor penting dalam memahami sesuatu, Kesadaran subjek dalam memahami dan memproyeksikan makna sesuatu tidak harus dianggap sebagai suatu tabula rasa sebagaimana ini muncul dalam 'fenomenologi Husserl”. Bagi Heidegger, persepsi diri atau sikap a priori tidak harus dibuang atau dikesampingkan, karena hal ini tidaklah mungkin. Sikap a priori adalah isi dari kesadaran seorang knower sebagai wujud internalisasi nilai-nilai dari tradisi yang mengitarinya. Sikap ini tidak negatif tetapi justru sebaliknya. Ia sebagai keterbukaan awal dalam menghadapai suatu realitas, dan bukan sebagai tujuan. Sebagai sebuah kondisi awal, ia kemudian mengembangkan horisonnya secara dialektik dengan the others.

Masyarakat Tengger adalah konstruksi masyarakat yang dengan segala pengalaman hidupnya, situasi dan kondisi yang mengitarinya dalam memandang hidup dan dunia, memahami dan menginterpretasikan hidup, alam dan lingkungannya sebagaimana faktisitasnya, miliu yang melingkupunya. Oleh karena itu jika dilihat dari lingkup masyarakat Tengger yang sarat dengan makna eksistensial dan nilai-nilai religius, maka masyarakat Tengger dalam memandang hidup dan keterkaitannya dengan 'dunia sana' sangat terpengaruh dengan makna-makna eksistensial tersebut.

Terkait dengan mitos Jaka Tengger dan Rara Anteng dapat dilihat dengan: Pertama, dalam memahami mitos bukan hanya berhenti ketika ditemukan bangunan logika yang mendasarinya, akan tetapi memahami mitos harus lebih diperluas, dan diperdalam budaya masyarakat tersebut. Kedua, dimunculkan konsep mytheme (miteme), suatu konsep yang menghubungan relasi-relasi terkait antar tokoh. Pentingya untuk mengungkap keterkaitan antar tokoh agar dapat dikuak apa yang sebenarnya terjadi. Ketiga, menggunakan konsep fonem yang bersifat universal namun juga kultural, fonem berada dalam peralihan dari nature ke culture. Fonem adalah sebuah tanda yang tidak bermakna dan tidak mempunyai acuan, ia dapat bermakna ketika telah dirangkai dalam suatu kata atau morfem. Konsep ini diterapkan dalam fenomena pernikahan antar kelompok, 
pertukaran sosial, dan relasi-relasi-relasi kekerabatan serta strategi analisis struktural yang menghubungkan relasi-relasi sosial dengan relasi-relasi lain dalam mitos.

Di samping itu, dalam pandangan Levi-Struss, mitos dimaknai dalam dua hal, yakni model of dan model for, Model of berarti mitos dipandang sebagai model untuk menafsirkan berbagai peristiwa yang terjadi, dan dalam kerangka berpikir tertentu, yang kemudian tidak menimbulkan kebingungan dan kecemasan. Sementara model for, berarti mitos dijadikan model untuk membangun sebuah kehidupan sosial yang diinginkan, dicita-citakan, sehingga mitos menjadi sumber inspirasi untuk mengatasi berbagai kesulitan yang dihadapi. Pemahaman mengenai model mitos ini sangat baru untuk kemudian bisa diterapkan dalam memahami mitos yang berlalu lalang diatas kita semua.

Paradigma masyarakat Tengger tentang alam sangat bersifat relasional, artinya alam dipahami sebagai sesuatu yang tidak bersifat meterial, tetapi spiritual. Keyakinan transendensi pada alam diejewantahkan dalam sebuah cara pandang yang melihat bahwa alam mampu memberi mereka kebutuhan ekonomis. Oleh karena itu, manusia dilarang untuk merusak alam, dan tindakan yang paling arif adalah menyelaraskan diri dengan alam. Ketika berbagai bencana alam terjadi pada mereka maka mitos-mitos yang berhubungan dengan kemurkaan alam sangat dominan mewarnai pola pikir masyarakat Tengger.

Mitos memang merupakan ekspresi yang sangat hidup mengenai relasi manusia dengan ruang lingkupnya dan keseluruhan lingup hidupnya. Ia menjelaskan tentang dirinya, asal usulnya, legitimasi kekuasannya, nasib dan keberutungannya, bahkan hidup dan kematiannya. Tetapi tidak hanya mengenai dirinya, melainkan mengenai relasinya dengan alam. Api, angin, laut, petir dan seterusnya semua dalam mitos bukanlah tampil sebagaimana adanya. Singkatnya, seluruh aktivitas alam sangat terkait dengan eksistensi manusia.

Begitu juga dalam masyarakat Tengger yang mempercayai mitos Rara Anteng dan Jaka Tengger merupakan bentuk kepatuhan manusia kepada Sang Hyang Widhi (menjalankan perintah agama) dan mau bekerja keras untuk kelangsungan hidupnya dengan tetap 
mengedepankan kelestarian alam, yakni terwujudnya kearifan ekologis, agar manusia tidak mendapatkan murka dari alam yang mempunyai kekuatan otonom. Ketakutan pada kekuatan alam memaksa alam inilah yang berdampak pada refleksi hidup seharihari, yakni. Pertama, kepatuhan mereka pada tradisi nenek moyang. Kedua, konsep hidup yang menyatu dengan alam, hidup sederhana, jujur, penuh toleransi, ramah dan suka bergotong royong. Hal ini juga menggambarkan budaya spiritual yang bersifat non-fisik nampak terlihat dalam perilaku, sikap hidup penduduk yang toleran, dan patuh pada pemimpin.

Mitos Rara Anteng dan Jaka Tengger juga bisa dimaknai sebagai bentuk peleburan eksistensi manusia. Eksitensi manusia yang dilebur untuk bisa menumbuhkan eksitensi-eksitensi yang baru. Sebuah bentuk pengorbanan yang dilakukan oleh anak terakhir pasangan Rara Anteng dan Jaka Tengger tentu saja bukan hanya sekedar peneladanan bahwa pengorbanan dalam setiap hidup itu sangat dibutuhkan meskipun dirinya sendiri menjadi korban, tetapi lebih dari itu. Bahwa makna eksistensi manusia sangat terkait dengan relasinya dengan yang lain. Karena bersentuhannya dengan yang lain pula menimbulkan ke-ego-an manusia disublimasikan begitu rupa untuk sebuah tujuan yang lebih tinggi, yakni hidup selaras dengan Tuhan, manusia dan alam.

\section{E. Identitas Lokal yang Tetap Permanen}

Pada masyarakat suku Tengger, upacara adat yang dikaitkan dengan nilai-nilai keberagamaan yang mereka anut dan diyakini kebenarannya senantiasa dilakukan dengan memperhatikan berbagai prosedur dan tata cara pelaksanaannya. Sistem upacara keagamaan meliputi sistem nilai dan sistem norma keagamaan, ajaran kesusilaan, dan ajaran doktrin religius lainnya yang mengatur tingkah laku manusia dalam kehidupan bermasyarakat dan sekaligus menjadi rujukan dalam bertindak. Sehubungan dengan hal ini maka di dalam segala aspek kehidupan, manusia membutuhkan rasa kepercayaan, termasuk di dalamnya aspek agama. Kenyataan menunjukkan bahwa sering kali dijumpai bentuk-bentuk kepercayaan yang berbeda-beda, masing-masing bentuk itu kemungkinannya mengandung nilainilai kebenaran dan kepalsuan yang bercampur baur. Oleh karena 
itu, faktor kepercayaan mutlak dalam agama, malahan agama tiada lain dan suatu bentuk yang diakui dan diterima sebagai kebenaran yang tertinggi atau mutlak.

Pernyataan di atas secara implisit menggambarkan manusia sebagai makhluk religius wajib mempercayai agamanya sebagai suatu kebenaran yang harus dipatuhi dan diyakini. Segala aspek kehidupan manusia yang landasannya sudah diatur di dalam agamanya selanjutnya diwujudkan dalam kehidupan sehari-harinya, sehingga mempunyai arah yang jelas.

Semua prosedur upacara religius pada masyarakat suku Tengger juga mengalami hal yang sama, seperti yang telah dijelaskan di atas. Bahkan masyarakat suku adat Tengger sangat patuh dan taat pada semua aturan yang telah mereka sepakati. Melalui peran dukun dan para pemuka atau tokoh masyarakat yang sangat kharismatik, orang Tengger sangat memperhatikan semua prosedur yang telah ditetapkan untuk mendukung kelangsungan suatu upacara. Karena memang bagi masyarakat suku Tengger upacara merupakan bagian hidup dan sekaligus menjadi simbol dalam memaknai hidup dan berinteraksi dengan lainnya. Katakutan pada kekuatan alam inilah yang berdampak pada refleksi hidup sehari-hari, yakni; pertama, sangat patuh terhadap kepercayaan pada zaman Majapahit dan melakukan upacara dengan penuh kepatuhan; kedua, konsep hidup yang menyatu dengan alam, hidup sederhana, jujur, penuh toleransi, ramah, suka bekerja keras, dan gotong royong ${ }^{26}$.

Dalam konsepsi homo religious, kisah-kisah tentang penciptaan dunia dan segala peristiwa yang mengakibatkan dunia ini ada tersimpan dalam mitos-mitos kosmogonis dan mitos-mitos asal usul. Mitos kosmogonis mengkisahkan terjadinya dunia secara keseluruhan. Mitos asal-usul mengisahkan segala kejadian asal-usul segala yang ada di dunia sekarang ini. Seperti manusia, binatang, pulau, tempat suci, tumbuh-tumbuhan dan seterusnya. Kisah mitos kosmogonis terjadi di alam dahulu kala, di waktu suci, yang dilakukan oleh para dewa, para leluhur, dan nenek moyang.

Dalam pandangan masyarakat Tengger kisah-kisah mitos itu benar dan tak terbantahkan. Mereka mengalami sendiri apa

\footnotetext{
${ }^{26}$ Novilia Rosaliana, "Proses Perubahan Sosial Masyarakat Tengger”, Skripsi, UMM, 2001, h. 24.
} 
saja akibat terhadap dirinya dari segala peristiwa yang dikisahkan dalam mitos mitos tersebut. Oleh karena itu, masyarakat Tengger juga mencari-cari norma-norma bagi kehidupannya. Bagi mereka mitos lalu merupakan arketipe, bersifat eksemplaris dan paradigmatis, yang wajib diteladankan dan di contoh. Transmisi norma ini secara struktural melalui para dukun yang kharismatik, di samping juga melalui keluarga. Mereka juga beranggapan bahwa segala perbuatan manusia tidak mempunyai nilai dan arti pada dirinya sendiri. Tindakan manusia hanya akan mempunyai arti dan nilai kalau meneladan tindak paradigmatis sebagaimana dikisahkan dalam mitos-mitos. Norma tata kelakuan, yakni meneladan mitos-mitos ini berlaku untuk segala macam perbuatan manusia, baik dalam ritus atau upacara, dalam menanam tumbuh-tumbuhan, berburu hewan, ataupun pada sikap sesama manusia.

Nilai-nilai dan norma-norma seolah-olah menjadi polisi lalu lintas yang mengatur masyarakat. Ketaatan untuk menjalankan tradisi leluhur adalah sesuatu yang tidak bisa ditawar lagi. Hal itu terwujud dari begitu banyaknya model upacara adatyang tetap mereka laksanakan. Bagi suatu masyarakat Tengger, terutama pada masamasa kelahiran, pernikahan, kematian merupakan persimpangan lalu lintas lintas, di mana dewa-dewa dan mitos-mitos kuno menjalankan fungsinya.

Era kultural dalam kebudayaan menurut Ibrahim Ibn Sayyar an-Nadham -seorang pemikir Mu'tazilah ternama- terdapat kemungkinan ada dua gerakan, yakni gerakan statis (harakah i'timad) yaitu gerakan yang tetap pada tempatnya semula, dan gerakan dinamis (harakah naqlah) gerakan yang mengakibatkan perpindahan dari satu tempat satu ke tempat yang lain. Yang terjadi dalam gerakan statis adalah fase-fase pemikiran senantiasa bersifat akumulatif, tumpang tindih dan saling kompetensi, ia tidak "menyatu" dan juga tidak "terbagi". Dan yang terpenting bagi saya adalah bahwa gerakan dalam kebudayaan masyarakat Tengger merupakan gerakan statis, dengan demikian era kultural masyarakat Tengger adalah era yang "stagnan" 27.

Era kultural masyarakat Tengger dapat dikelompokkan

${ }^{27}$ M. Abid al-jābiri, Naqd al-Aql al-Arabì (1), Takwin al-'Aql al-'Arabi, Dirāsah Tah̦iliyah li Näum Al-Saqāafi al-'Arabi, (Beirut: al-Markaz al-Saqāfi al-'Arabiyyah, 1993), h. 65-57. 
menjadi empat era. (1). Era kerajaan Majapahit, era di mana identitas lokal masih menunjukkan kemurniannya. (2). Era agama Hindu-Budha yang masuk pada masyarakat Tengger, era ini kedua peradaban kultural terlibat intens, tetapi tetap saja mereka dalam melaksanakan kegiatan keagamaannya tidak menunjukkan ciri sebagai pemeluk agama Budha; (3). Era Islam (kerajaan Mataram Islam) yang tak mampu mempengaruhinya, perlawanan demi perlawanan dilakukan oleh masyarakat Tengger, baik secara politik maupun budaya; (4). Era penjajah atau kolonial Belanda yang mampu 'menguasai' wilayah Tengger. Lantas, persoalannya adalah apa yang tetap permamen dalam 'kesadaran kognitif masyarakat tengger ketika harus melewati empat era kultural yang bergelombang, berputar, memanjang, konflik ontologis dan bahkan secara intens bergumul?. Menurut saya, yang tetap ada dan permanen adalah sistem pengetahuan lokal dalam memandang hidup, dunia, dan lingkungannya. Inilah salah satu dimensi ontologis yang tetap melekat dalam kesadaran masyarakat Tengger.

\section{F. Penutup}

Melacak dimensi metafisik dalam upacara Kasada adalah tidak hanya sekedar melihat ritual tersebut dari dimensi empiris belaka. Di samping nilai-nilai ketimuran sangat kuat dalam ritual tersebut, namun pelacakan dimensi metafisik melampaui simpulan sementara orang yang melihat bahwa dunia timur adalah dunia atau hidup yang dibangun di atas paradigma harmonis, selaras, dan sebangun dan seterusnya.

Pertanyaannya sekarang, betulkah dimensi metafisik dunia timur demikian?. Jika bicara dalam konteks peradaban, maka sebuah peradaban akan hancur kalau tidak mengikuti arah metafisik tersebut. Persoalannya lagi adalah dalam keselarasan, apakah tidak ada sesuatu yang berubah?. Tetap dan berubah adalah problem penting yang harus ditemukan dalam berbagai ritual di dunia ketimuran. Di samping itu, pembicaran metafisika juga harus terkait dengan keilmuan lain. Jika dalam konteks tertentu, dibutuhkan analisis yang harus meminjam 'filsafat agama', maka mengapa tidak? Toh, dalam refleksi filsafat agama juga mengarah pada pencarian dimensi metafisik. 
Karena itu, menurut saya, pembicaraan metafisik lebih dari sekedar itu. Metafisika melacak, memaknai, merefleksikan dan bahkan bisa menjadi pengarah dalam memaknai dunia ke depan. Ini terbukti dalam, pencarian dimensi metafisik yang dilakukan oleh para filsuf Yunani. Ketika mitos begitu luas menggejala dan bahkan membakar dunia, maka filsafat datang memadamkannya dengan mampu menemukan the first principle dari setiap pengada. Masyarakat Tengger dengan segala ritual dan upacara Kasada yang diwarnai dengan mitos, dapat ditemukan dimensi metafisiknya adalah kehidupan untuk semua.

\section{Daftar Pustaka}

al-Jabiri, M. Abid, Naqd al-'Aql al-'Arabi (2), Bunyah al-'Aql al-'Arabi, Dirāsah Tahliliyah li Nazum Al-Saqäfi al-'Arabi, Beirut: alMarkaz as Saqōfi al-'Arabiyyah, 1993. Peursen,C. A Van, Strategi Kebudayaan, Yogyakarta: Kanisius,1988.

Astutik, Juli, “Makna Ritual Upacara Kasada dalam Perspektif Antropologi, dalam Agama Tradisional", Yogyakarta: Lkis, 2003.

Beatty, Andrew, Variasi Agama di Jawa Suatu Pendekatan Antropologi. Jakarta: Murai Kencana, 2001.

Bertens, K., "Yang Sakral dan Yang Profan dalam Penghayatan Tradisional Homo Religious Menurut Mircea Eliade". Jurnal Ulumul Qur'an.

Chatterjee, Margaret, The Existentialist Outlook, New Delhi: Orient Longman Ltd., 1973.

Gassier, Ernst, Manusia dan Kebudayaan, Sebuah Esai tentang Manusia. Jakarta: PT Gramedia Utama, 1990.

Hamersma, Harry, “Eksistensi dan Transendensi dalam Metafisika Karl Jaspers", dalam Manusia Multidimensional: Sebuah Renungan Filsafat, M. Sastrapratedja (ed.). Jakarta: Gramedia, 1983.

Heidegger, Martin, Being and Time, terj. J. Marquairie, et-al. New York: Harper \& Row, 1962. 
Mangunhardjono, "Homorelegiosus menurut Mircea Eliade", dalam Manusia Multidemensional: Sebuah Renungan Filsafat, (M. Sastrapratedja. ed). Jakarta: Gramedia, 1983.

Muslimin, “Pengaruh Kepemimpinan Uwa' terhadap Motivasi dan Disiplin Kerja Masyarakat Tolotang di Kabupaten Sidrap". Tesis, Universitas Hasanuddin Ujung Pandang,1996.

Nurudin (ed.). Agama Tradisional: Potret Keraifan Hidup Masyarakat Samin dan Tengger, Yogyakarta: Lkis, 2003.

Rosaliana, Novilia 'Proses Perubahan Sosial Masyarakat Tengger', Skripsi, UMM, 2001.

Siswanto, Joko, Metafisika Sistematik, Yogyakarta: Taman Pustaka Kristen, 2004.

Sontaq, Frederick, Pengantar Metafisika, Yogyakarta: Pustaka Pelajar 2001.

Supriyano dan Wirtayuhangga, Misjana, Di balik Keindahan Gunung Bromo, Probolinggo: Tanpa Penerbit, 1991.

Suseno, Frans Magnis-, Etika Jawa: Sebuah Analisa Falsafi tentang Kebijaksanaan Hidup Jawa, Jakarta: Gramedia, 1985.

Suyitno dan Sapari, Achmad, Mengenal Masyarakat Tengger. Surabaya: Media Alas Dayu, 1999. Tuanaya, Malik M. Thoha, "Pura dan Masjid: Konflik dan Integrasi Pada Suku Tengger", Tesis, Universitas Muhammadiyah Malang, 2000.

Thaha, A. Malik, Tren Pluralisme Agama, Jakarta: GIP, 2005

Widyaprakoso, Simanhadi, Masyarakat Tengger: Latar Belakang Daeah Taman Nasional Bromo, Yogyakarta: Kanisius, 1994. 
Mohamad Anas

halaman ini bukan sengaja dikosongkan 